\title{
O retorno à natureza na ficção brasileira do começo do século XXI
}

Luciano Brito $^{1}$

Existe um esforço claro de retorno à natureza na literatura brasileira nos últimos anos: a floresta amazônica em Órfãos do Eldorado (2008), de Milton Hatoum, a praia catarinense em Barba ensopada de sangue (2012), de Daniel Galera, a reserva da tribo Krahô em Nove noites (2002), de Bernardo Carvalho, o sertão cearense em Galileia (2008), de Ronaldo Correia de Brito, e outros. É como se as tentativas de legitimar uma historiografia literária localizada nos grandes centros urbanos, São Paulo ou Rio, de Machado de Assis a Patrícia Melo, não importa quantos anos passem e o quanto essas cidades se multipliquem, estivessem sempre sob a ameaça de sucumbirem ao poder metafórico e simbólico das representações de praias, florestas, rios profundos. Uma operação inédita no entanto parece se efetuar nas últimas décadas, em que a natureza não parece deter mais - segundo uma historiografia literária nacionalista - sua propriedade mais marcada: a de ser o melhor retrato do país, o que teríamos "de melhor", inigualável e incomparável com o resto do mundo, especialmente se por resto do mundo estivermos nos referindo à oposição colônia e império, ou Primeiro Mundo e Terceiro Mundo, Norte e Sul. Do romantismo indianista à tropicália, é em todo caso o que nos foi repetido incessantemente, foi esse o papel dos nossos coqueiros, pampas e florestas: nos destacar, não raro nos separar dos outros espaços mundiais.

Tais representações e leituras não perderam seu valor de nostalgia e resistência. Mas elas também contribuíram para a instalação de um forte autoctonismo e/ou

\footnotetext{
${ }^{1}$ Université Sorbonne Nouvelle - Paris 3
} 
isolacionismo culturais, que sequer correspondem às bases transnacionais dos movimentos modernista e tropicalista a que costumam ser relacionadas.

Os três romances discutidos aqui possuem uma relação estranha com o meio nãohumano. Num caso, a antiga metropolização de Manaus é sobreposta a uma cidade submersa sob o rio Amazonas; nos outros dois, as personagens, saindo de grandes centros urbanos, São Paulo num caso e Porto Alegre no outro, são de modo hipnótico e por razões misteriosas empurradas em direção a florestas e águas profundas. O mistério que o protagonista de Nove Noites quer desvendar nas matas da fronteira do Tocantins não parece ser sequer seu ou de compatriotas, mas de toda a humanidade. A representação da natureza, nos três casos, parece ir em duas direções:

(1) a de perder tal qualidade de objeto nacional para se constituir como um espaço planetário; nos romances de Bernardo Carvalho e de Galera, o natural guarda um mistério que excede fronteiras nacionais, em tramas que se desenvolvem por intuições paranoicas (como no caso de Nove noites), encantamentos (como no caso de Órfãos do Eldorado) e/ou sob a forma de uma enquete policial (em Barba ensopada de sangue);

(2) a de representar um aparato imagético imbatível para invalidar a existência da metrópole, se esta ainda for compreendida como um antigo símbolo modernista de progresso; é nas florestas e nas ondas do mar que os narradores vão buscar as chaves necessárias para a intriga, é no espaço mais longe possível de postes de luz e de entradas de metrô que eles se aproximarão do objeto que buscam, e somente lá uma possibilidade qualquer de redenção. Mesmo no romance de Hatoum, em que o espaço natural redentor é urbanizado (o Eldorado é afinal uma cidade), é subentendido que se trata de uma cidade por assim dizer mágica, obra de um mistério sobre-humano. O retorno para a grande cidade, como no fim do romance de Carvalho, acontece com algum alívio: 
agora o narrador está de volta à segurança do espaço urbano, distante do que mais o perturba mas tranquilo para seguir com a vida. A floresta fechada e o sertão ficam no passado, como objetos reveladores e assombrosos que tiveram de ser deixados pra trás. Eles seriam o que Mark D. Anderson (2010) chamaria, a respeito da natureza monstruosa de Euclides da Cunha, "ecologias de abjeção"2.

Apesar disso, em seguidas tentativas na nossa história literária, a representação da natureza foi associada a um projeto específico de construção de uma literatura nacional: a prosa indianista de José de Alencar, o projeto modernista em geral. Guarani, Iracema e Macunaíma vêm de e pertencem à natureza, são como que personificações naturais - eles não poderiam vir de uma cidade grande ou possuir raízes europeizadas, é o fato de serem absolutamente autóctones - e consequentemente brasileiros - que faz deles objetos de representação únicos. Ao invés de localizar seu sentido em torno da noção de brasilidade, a natureza reapareceria nesses três romances como um poder metafórico mundial - revelador, inviolável, sedutor, não raro destrutivo - manifestado de acordo com a flora e fauna locais de cada narrativa: ondas do mar, tempestades litorâneas, rios, ou baleias, cobras sucuris, cadelas latindo misteriosamente nas últimas páginas. O que pareceria estar por trás disso é a sugestão de que a grande cidade, tal como ela já foi representada como o símbolo máximo modernista, precisaria se transformar, sob pena de ser atracada por galhos, cipós, submergida por águas profundas.

Entre a nostalgia de um projeto brasileiro, como repetido seguidas vezes, e o ressurgimento dos mesmos objetos como detentores de outros significados, existiria um percurso (é grande a tentação de utilizar uma metáfora associativa e dizer: como um

\footnotetext{
${ }^{2} \mathrm{O}$ estudo de Mark D. Anderson, além disso, é um exemplo que repensa a associação epistemológica entre natureza e nação, desde o começo do século XX. A partir de Euclides da Cunha, cuja representação da Amazônia seria "tudo menos harmônica", a natureza constituiria, ao contrário de paisagens homogêneas e paradisíacas, espaços de desintegração nacional.
} 
rio!) que poderia constituir uma revisão historiográfica. Num outro argumento, a questão seria de repensar epistemologicamente a associação entre nação e natureza onde justamente ela não faria sentido algum.

\section{O Vendedor de frutas (1925) ${ }^{3}$. A natureza no imaginário cultural nacional}

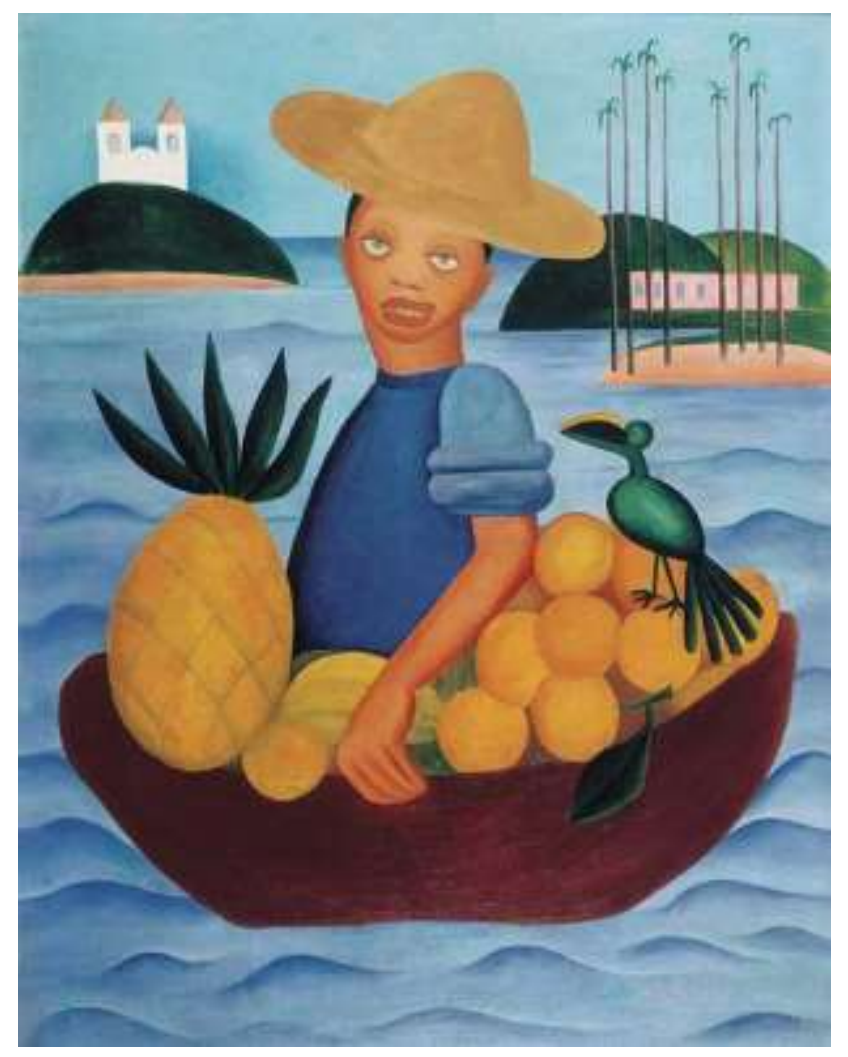

Foi Luiz Costa Lima (1996), numa das primeiras edições da Revista Brasileira de Literatura Comparada, que comentou não apenas a associação antiga entre as noções de Estado-nação e literatura ${ }^{4}$, mas que nos relembrou da descrição da natureza como um recurso político e estilístico dos mais recorrentes para legitimar tal ligação:

${ }^{3}$ O Vendedor de Frutas, Tarsila do Amaral, 1925, óleo sobre tela, 108,5 x 84,5 cm, Coleção Gilberto Chateaubriand, MAM/RJ, Rio de Janeiro.

Brasiliana - Journal for Brazilian Studies. Vol. 3, n.1 (Jul. 2014). ISSN 2245-4373. 
Tendo sempre por pressuposto o leitor de alma sensível, o realce das cenas da natureza asseguraria às literaturas latino-americanas a condição para que pudessem ter um lugar ao lado das literaturas maduras. Se estas se particularizariam pelos gênios que pudessem convocar, as latino-americanas se diferenciariam pela singularidade de sua natureza. (Costa Lima, 1996: 36)

Existe outra uma questão interessante, para além da ficção por trás da associação entre nação e natureza: o fato de essa narração ser um projeto que toca a representação das paisagens e das personagens, mas não os projetos estéticos em si. É conhecido que o modernismo não apenas tinha uma intenção "antropofágica", para utilizar o termo de Oswald de Andrade, como queria inverter o sistema de transações unilaterais e exportar a produção local para culturas hegemônicas. É sabido além disso que o projeto transnacional era tão óbvio para Oswald de Andrade ao ponto de este não ter problemas em apresentá-lo de modo lúdico e auto-debochado, como o é o próprio nome “movimento antropofágico." Finalmente, o fascínio do movimento modernista por representações da natureza e objetos autóctones, muito possivelmente graças à recepção da tropicália, é uma memória evidente; é interessante lembrar que ele também é acompanhado de um igual fascínio pela urbanização, pela chegada dos bondes elétricos e pela experiência metropolitana, em outros quadros de Tarsila do Amaral (A Gare), e também na produção de Oswald e Mário de Andrade (em Paulicéia Desvairada, na longa passagem de Macunaíma em São Paulo.)

\footnotetext{
${ }^{4}$ Para outro comentário a respeito e a subsequente apropriação dessa associação pelos departamentos universitários, ver Meltzer, 2009. O argumento é de mostrar como a concepção de essências nacionais, patrocinada por uma suposta unidade divina da nação, funcionou como um sistema, muitas vezes inconsciente, de exclusão cultural e política, apoiado numa memória coletiva nacional inventada.
}

Brasiliana - Journal for Brazilian Studies. Vol. 3, n.1 (Jul. 2014). ISSN 2245-4373. 
Se assim as raízes do modernismo brasileiro são claramente urbanas e transnacionais, é certo que a apropriação das culturas europeias e hispano-americanas pelo que nos habituamos a chamar de Semana de Arte Moderna não apenas é disfarçada nas representações da natureza como vai, mais uma vez, no sentido de legitimar uma noção de brasilidade, de "coincidência da primeira construção brasileira no movimento de reconstrução geral", do Manifesto Pau-Brasil. E, mais uma vez, para recriar o "objeto brasileiro", apesar do esforço metodologicamente construído a partir da passagem entre línguas e culturas (o cubismo europeu, a mitologia tupi-guarani) e do fascínio por grandes cidades, a representação do objeto natural rejeita rigorosa e cuidadosamente a presença do elemento cosmopolita e estrangeiro. $\mathrm{O}$ "brasileiro" continua sendo aquele que vêm da terra e pertence à terra - um lugar que, como outro, não há. Macunaíma segue como o exemplo mais habitual ("Sou Americano e meu lugar é na América", o herói diz para os "manos" a certa altura, antes de virar a Ursa Maior.)

Em o Vendedor de Frutas, de Tarsila do Amaral, a construção de uma essência nacional associada a elementos naturais, como em Macunaíma, fusiona paisagem e personalidade. É um retrato de um rapaz mulato (e bronzeado, é o que parece dizer o tom alaranjado do óleo), por volta dos vinte e pouco anos, sozinho e acompanhado de um abacaxi, laranjas e de um pássaro verde que espontaneamente pousa ao seu lado embora o menino o ignore. Quase arrogantemente, e sem fixar os olhos em nenhum ponto específico (o que pode ser interpretado como um sinal de distração, ameaça ou demência), o rapaz apoia os dedos de modo possessivo sobre as bordas do barco, que magicamente tem a forma de um cesto de frutas.

Nada no rapaz indica traços de urbanidade ou de civilização, nos termos ocidentais que Tarsila do Amaral conhecia bem: nômade, primitivo, ele possui um tipo de conhecimento único, talvez sequer traduzido em linguagem verbal (é difícil dizer se o rapaz fala português). Graças à falta de cílios e à sobrancelha atenuada, o olhar é o de 
alguém que não dorme, como um animal de guarda sempre atento à possibilidade do ataque contra a mercadoria ou contra o coqueiral atrás. Ele não tem nenhum senso de humor.

Que as cores do quadro, como as do Abaporu que ela pintaria em seguida, sejam as mesmas da bandeira do Brasil, adotada há então menos de trinta anos, não é exatamente um hieróglifo. O jovem vendedor de frutas concentra a sua energia nos olhos de sentinela que parecem se projetar para o oceano, como um cão protetor, e na boca carnuda ameaçante. O chapéu inclinado adiciona à animalidade uma aura de mistério.

O Vendedor de Frutas pode ser compreendido, em grandes linhas, como uma reação de uma ex-colônia em busca de uma identidade cultural, num momento em que a principal estratégia estética de resistência é a de utilizar objetos naturais incessantemente. Um argumento mais longo poderia mostrar a prosa de Jorge Amado como um segundo momento dessa resistência. Se Tieta é uma reviravolta literária, é também porque agora o herói - a heroína - nacional não é mais um selvagem autóctone restrito às praias, mas uma exilada amiga do estrangeiro; por um lado animalesca, "pastora de cabras", e ao mesmo tempo uma francófila urbana, de volta à Bahia de batom vermelho e calças Levi's. Não há necessidade de dizer que uma tal personagem teria sido impensável no primeiro modernismo nacional. Não há necessidade de dizer que seu caráter nacionalista faria pouco sentido hoje em dia.

A literatura brasileira contemporânea, como numa espécie de rastro nostálgico dessas representações, pouco a pouco abandona a natureza ao planeta inteiro. Como o próprio Costa Lima diz numa entrevista recente, a produção literária atual iria rumo à internacionalização da intriga (Costa Lima, 2014), um movimento que, é o argumento aqui, levaria consigo selvas, rios e sertões. Esses, agora, ganhariam traços de uma hospitalidade aberta. E se essa abertura é necessária, é porque a ilusão - estou usando o 
termo no melhor dos sentidos - de uma "nacionalização plena" dos espaços e objetos naturais não representaria mais, agora, uma resistência estética ou política, mas uma força anticosmopolita e discriminatória. O texto que eu tenho em mente aqui é o de Edward Saïd.

\section{"Isto é para quando você vier": Natureza e paranoia em Nove noites}

Os arredores de Carolina, cidade na divisa entre o Tocantins e o Maranhão, no romance de Bernardo Carvalho, são mais divertidos de noite que de dia. O Xingu, o parque indígena onde vive a tribo dos Krahô, o "Xingu da minha infância" (Carvalho, 2002: 53) do narrador, é para onde converge a intuição paranoica da trama: foi lá que o arqueólogo Buell Quain, então aos vinte e sete anos, em 1939, se matou, dando início à curiosidade do narrador, sessenta anos depois, de descobrir o que aconteceu. Mas assim como a busca pelos mortos não resultará em nada, tampouco a mata fechada dará qualquer resposta. Se a irresolução seria destrutiva, o subtexto moral da trama não está em forçar uma conclusão, mas em desfazer a destrutibilidade da irresolução; fazer com que o narrador aprenda a lidar com o que ele não vai descobrir.

Nas palavras de um segundo narrador, Manuel Perna, com quem o arqueólogo teria visitado a aldeia, "vejo que foram nove noites. Mas foram como a vida toda" (id.: 41), era "o paraíso e o inferno." (id.:43) Antes de ir à aldeia dos Krahô, Buell Quain, ainda estudante, já havia conhecido uma outra tribo numa ilha do Pacífico e passado quatro meses com os Trumai, perto do Krahô, para quem ele falou a Manuel "do medo." É esse mesmo imaginário apavorante que o narrador principal, que vai atrás das pistas de Bull, compartilha, e o Xingu que havia conhecido quando criança é o mais próximo do que tem como a "representação do inferno." (id.:54). 
Suicídio, terror, inferno: é essa a imagem da floresta para onde ainda assim o narrador, na vida adulta, retorna. A irracionalidade que encoraja o sujeito a voltar e a descobrir o que teria acontecido com o antropólogo é apresentada como um retorno à infância, como se apenas a floresta tivesse os subsídios de explicar mistérios originais questões pessoais do narrador, o pai, a sexualidade, etc. Na aldeia, o narrador, como que numa metonímia de todo homem urbano, "é a criança deles." (id.:97). E para se aproximar da "fonte" que lhe dará as respostas, o ritual é necessariamente de desurbanização: "Os indiozinhos me carregaram. Era como se estivesse no meio de uma correnteza. Não adiantava resistir. Pelo que pude entender, queriam me ver nu, me deixar igual a eles." (id.:60).

Ele, o narrador, sabe que, se insistir em querer obter os esclarecimentos por rituais naturais, acabará levando até o último termo o que aconteceu com Buell Quain: flagelar-se dementemente com uma navalha, e em seguida se enforcar. (Afinal é isso que Buell Quain representa: um duplo, um movimento que na estrutura narrativa do romance é melhor exemplificado pela alternância entre a voz do Manuel, em itálicos, e a do narrador principal.) É assim que Manuel descreve o último encontro que teve com o arqueólogo:

Dali em diante ele e os índios seguiam a pé e eu voltava para Carolina só, levando comigo o que ele me dissera a ecoar no fundo da cabeça. Ao vê-lo partir com os índios pela manhã, virando-se para trás, a me acenar com a mão pela ultima vez antes de desaparecer entre os arbustos, não queria imaginar, embora por um momento o pensamento tivesse me passado pela cabeça, que nunca mais nos veríamos, que aquela era a nossa despedida. (id.:115) 
O que acontece, o significado final da estadia de Buell no parque florestal do Xingu, é compreendido como uma preparação para a morte. A falta de explicações em torno da vida pessoal do arqueólogo ou suas motivações, em contraste com a sua insistente ida a aldeias indígenas em diferentes lugares do mundo, é onde reside a força do romance para que seja claro - claro no sentido de visível e não de explicável - o poder convidativo, irresistível e apesar disso destruidor da mata:

Quando entendeu que precisava voltar, que fora longe demais, já não tinha forças para a caminhada. Todo bicho, nem que seja cobra rastejante, nem que seja uma lesma, um caracol, nem que seja uma vez na vida, quando olha para uma árvore ou para uma pedra ou para um pedaço de céu, vê a totalidade do universo e compreende por um instante o que é, onde está e o que se passa à sua volta. Depois da morte dele, saí à procura dessa árvore, tentando entender. (...) A comprovação eu só teria se exumasse o cadáver com as próprias mãos. Muita coisa não se pode desenterrar. (id.:118-119)

A visão dessa "árvore", é o que a narrativa de Manuel parece nos dizer, é que, mesmo que nos mostre o universo inteiro, "a totalidade do universo", ela não permite retorno subsequente à vida. A visão da natureza é ao mesmo tempo revelação e castração.

O que Luiz Costa Lima diz por "quebra das barreiras nacionais" a respeito da produção literária atual, em Nove noites poderia ir em algumas direções: no interesse mútuo de Buell por aldeias brasileiras e tribos do Pacífico, no fato de Buell ser norteamericano (algo no mais impensável em outros tempos da ficção nacional), e, finalmente, na falta de sentimento nacional seja da parte do narrador seja da parte dos índios Krahô - a identificação que existe entre eles e o narrador, ou ainda entre o 
narrador e Buell, em nada são acompanhadas de algo que se assemelhe a um patriotismo. Se, ainda, fizermos uma leitura do romance levando em consideração questões coloniais, uma tentação inevitável por se tratar de uma narrativa que trata do encontro entre um estrangeiro e uma tribo de indígenas e, em seguida, entre alguém de São Paulo e uma comunidade rural no interior de Tocantins, estaremos de frente a mais complicações e desconstruções dos binários entre Primeiro Mundo e Terceiro Mundo, espaço metropolitano e espaço rural, etc.

No que diz respeito à imagem geral da natureza e da cidade, a maior ironia de Nove noites é o final. O narrador vai para Nova York encontrar o filho do fotógrafo para quem a narrativa em itálico de Manuel teria sido escrita, um homem de agora cinquenta e poucos anos que em sua juventude fugiu para a capital e lia poemas de Frank O’Hara. Logo se descobre que não há nada que comprove uma relação qualquer entre o tal sujeito e toda a trama em torno de Buell Quain. Curiosamente, todo o imaginário paranoico de Bernardo Carvalho poderia se encaixar perfeitamente, nesse final, com a imagem de uma cidade como Nova York, apocalíptica e terrível como é a sua representação mais comum no imaginário global - ainda mais num então recente onze de setembro. Ao contrário, Carvalho preferiu encerrar o livro com uma imagem serena da cidade, para onde o narrador vai para "se desencantar" (id.:142) e esbarra num sujeito algo bem-humorado, recitando poemas de resignação urbana de O'Hara. O efeito subsequente é o de contrastar com e reforçar o poder misterioso e paranoico da natureza - o Xingu do interior do Tocantins, agora definitivamente enterrado no passado. O verso de O'Hara que o personagem diz é "Estou virando a rua" (id.:148), "I'm becoming the street", como que o indício de que a reurbanização do narrador, ainda que ele não obterá nunca as respostas dos mortos, o encaminharia apesar de tudo para uma espécie de graça - leve, mundana, cotidiana, distante da tentação e monstruosidade das matas fechadas.

Brasiliana - Journal for Brazilian Studies. Vol. 3, n.1 (Jul. 2014). ISSN 2245-4373. 


\section{A sucuri de Milton Hatoum}

Se a floresta do Xingu em Bernardo Carvalho induz desde o começo o narrador a curiosidades paranoicas e à morte, o caráter destruidor da natureza em Órfãos do Eldorado é disfarçado sob uma aura (e um vocabulário) fantasistas: utopias encantatórias, seres da floresta e do mar que alegremente levam os habitantes de Manaus para o fundo do rio. A força mágica do Amazonas, apesar do título que poderia ser compreendido como infantil, puxa inocentes sonhadores às águas profundas, e antes de arrastá-los à Cidade Encantada, a lenda diz que a sucuri já os teria devorado (Hatoum, 2008: 34). E uma outra lenda falaria de botos que puxam mulheres ao fundo dos rios (id.: 64).

O efeito de inocência do texto de Hatoum faz com que a natureza não seja apenas, como em Carvalho, uma força de revelação e castração, mas uma utopia. Em Carvalho, tudo é sentido de suspense e paranoia: quem é Buell Quain? Por que ele se matou? Qual a relação dele com o narrador e com a história do pai? O que acontece na mata fechada e até onde ele podia ir? O projeto de Hatoum por outro lado é construir um imaginário mitológico, uma colagem de lendas em torno da região amazônica - o Eldorado, a visão de Manaus às vésperas da Segunda Guerra, os mitos sobre os animais e principalmente a força imagética do rio, através do qual o retorno à natureza é compreendido. Na história da literatura brasileira, estou pensando em José de Alencar, existem exemplos de um esforço parecido, em que a natureza fornece romântica e homogeneamente uma imagem de si lendária. Mas José de Alencar dificilmente utilizaria a lenda do Eldorado, que insere a geografia brasileira num contexto hispânico, em seu imaginário.

Se no final de Nove noites, o narrador vai à Nova York para "se desencantar", o que quer dizer: dar rumo à sua vida, em Órfãos do Eldorado a passagem do encanto ao 
desencanto ou vice-versa emula duas imagens perpetuamente repetidas: a visão de Manaus em rumo de se transformar na capital da Zona Franca e a imagem utópica do Eldorado ao longe, a cidade mágica no fundo dos rios, para onde nativos e imigrantes são levados por botos e sucuris. É para essas águas profundas que o narrador se dirige e é lá onde ele reencontrará a paz e Dinaura, sua paixão de juventude. Em Milton Hatoum, os personagens estão sempre à espera dessa sucuri, contra a nostalgia da cidade transformada e da urbanização desigual - uma ficção que nos é conhecida. Somente a sucuri salva e leva ao céu submerso.

O espaço aqui é internacionalizado ainda pela representação das imigrações libanesa, japonesa e judaica - não raro esquecidas na historiografia literária para não enfraquecer a noção homogênea e ficcional da nação - e pela colagem das lendas indígenas e hispânicas: é impossível conceber que essa natureza utópica possa encorajar ou se importar com uma representação nacional ${ }^{5}$. A principal dessas lendas, a do Eldorado, é para onde convergem três imagens na novela: os animais encantados, a visão de uma cidade no fundo das águas e finalmente a lembrança de Dinaura, "mulher anfíbia":

Acariciei os braços e os ombros de Dinaura, e admirei o rosto dela. O desejo no olhar cresceu. Não fiz pergunta, nem disse nada. Qualquer palavra era inútil para o amor urgente. Ventava com força. Ela não se assustou com as trovoadas, nem se esquivou do meu abraço. Eu guardava as palavras no meu pensamento. Um dia viajaríamos juntos, conheceríamos outras cidades. Ela olhava a outra margem do Amazonas, como num sonho. (id.:50)

\footnotetext{
${ }^{5}$ Se expandíssemos o argumento para um outro romance de Hatoum, como Cinzas do Norte, a queda das fronteiras seria ainda explicada pela própria imagem do exílio, através da personagem Raimundo.
} 
Dinaura, como as árvores de Nove noites que mostram a "totalidade do universo" e ao mesmo tempo a morte, é a principal obsessão do narrador; é uma nativa que desapareceu misteriosamente como se tivesse ido para a cidade mágica, apresentada ela mesma como "encantada". A busca por Dinaura, a espera da sucuri e a imagem do Eldorado são como que imagens que se justapõem em oposição à Manaus miserável por cima das águas ("a exportação de borracha, o emprego, o comercio, o turismo, tudo crescia (...) Se não plantarmos sementes de seringueira, vamos desaparecer...") (id.:33.) São Dinaura e Arminto os órfãos, os que nunca se reencontrarão e que nenhuma cobra poderá unir.

A imagem da natureza em Hatoum, contrariamente a de Nove noites que é a de ser um segredo nunca obtido, é apresentada como uma utopia agora perdida e pertencente ao além, duplicando a imagem de uma Manaus boêmia perdida; os cinemas, óperas do teatro Amazonas, o High Life Bar, a mercearia Cosmopolita, os bailes do Ideal, etc. A insistência de Hatoum com lendas, encantamentos, cidades mágicas embaixo de rios, utopias perdidas, é de algum modo a negação do desenvolvimento de Manaus tal como aconteceu em prol de um estado primitivo perdido:

Se eu fosse mais nova, ia embora deste terra, disse Florita.

Para onde?

Para outro mundo. (id.:89)

Assim como Proust "mitifica desmistificando" o glamour de uma Paris da belle époque, Hatoum apresenta o passado colonial de Manaus como um objeto desfeito, contra o qual resta a possibilidade do "outro mundo" (a ficção em si no caso de Proust, o Eldorado 
para Hatoum.) E assim como a novela começa com a lenda contada por uma índia sobre uma mulher atraída por um ser encantado e a sua fuga do marido até o fundo das aguas e o encontro com o amante num "mundo melhor", o texto também se encerra com uma cena distante da capital: uma ilha abandonada, também chamada Eldorado, habitada por baratas-cascudas onde todos "morreram e foram embora". Arminto queria chegar no Eldorado e, quando lá, o paraíso havia sido comido por baratas; sem esperanças vai envelhecer em Vida Bela. A espera por botos ou pela sucuri messiânica ("recebi cartas e bilhetes de pessoas que tinham sido seduzidas e depois perseguidas por seres do fundo das águas", "histórias de homens e mulheres, todos vítimas de um ser encantado que surgia em sonhos, cantando a mesma canção de amor") (id.:65) não lhe traria redenção alguma. Arminto volta para a tranquilidade de Vila Bela como uma pequena vitória intermediária: nem a salvação do Eldorado, nem a miséria de Manaus.

O território amazônico, seja em contextos políticos ou estilísticos, já encontrou outras vezes dificuldades para se integrar à nação; além de que, geograficamente, a Amazônia invade todos os países com os quais o Brasil faz fronteira ao norte. Culturalmente, seja no próprio Hatoum ou em produções como Fitzcarraldo, a floresta segue como uma "ecologia de abjeção", segundo o termo de Mark D. Anderson, de alienação e de exílio. Liberar a paisagem amazônica de todo patriotismo, contra todo patriotismo, não é um exercício que requer muito esforço.

Ainda sobre o texto de Hatoum, uma questão levantada é a desconstrução do binômio cidade e natureza. Não apenas Manaus é em grande parte confundida ou superposta à floresta amazônica (em muito graças à estrutura geográfica da cidade: “O coração e os olhos de Manaus estão nos portos e na beira do Negro") (id.:19), assim também o ideal do "profundo natural" do Eldorado é urbanizado; é uma Cidade Encantada, "rica, esplêndida, exemplo de harmonia e justiça social, onde as pessoas vivem como seres encantados" (id.:105-106), "brilhava de tanto ouro e luz, com ruas e 
praças bonitas." (id.:64.) Não existe modo de solucionar esse problema a não se admitirmos que não existe problema algum: que na realidade Hatoum não está escrevendo contra a cidade, mas contra um tipo de urbanização. Ele estaria ainda (mas esse argumento teria de ser desenvolvido mais calmamente em algum outro lugar) contra uma certa imagem modernista da cidade, então concebida como um símbolo máximo de progresso e uma ameaça à geografia natural "nacional"; não sendo mais esse símbolo nem essa ameaça, a Manaus de Hatoum seria algo outro e sem precedente.

Assim, nem todo o problema da novela gira em torno da espera pela sucuri mágica.

\section{Daniel Galera, trovoadas e ondas do mar}

A visão de sucuris messiânicas e de botos sedutores não entra na imaginação de Barba ensopada de sangue. O livro conta a ida de um rapaz à Garopaba, um vilarejo litorâneo no estado de Santa Catarina, para desvendar o mistério da morte do seu avô, um homem aparentemente violento e de força sobre-humana que décadas atrás morreu de modo terrível e acabou virando uma espécie de superstição para a população local. O jovem sofre de prosopagnosia, uma doença que o impede de registrar os rostos das pessoas. Chegando em Garopaba, ele aluga um apartamento e consegue um emprego como professor de natação; em paralelo, ele tenta desvendar o mistério em torno da história do avô e, a cada passo que ele avança, mais a população local o olha com desconfiança. No mais, o rapaz é inacreditavelmente parecido com seu avô Gaudério. Na última parte do romance, já sem esperança de descobrir o que quer que seja, ele sai pelos arredores de Garopaba rumo aos matagais à beira da estrada, sem mala ou roupas a mais, ou escova de dente ou celular, levando apenas a cadela do pai com a qual ele tinha vindo ao vilarejo. Sua barba nunca esteve tão longa. É quando coisas realmente estranhas 
começam a acontecer. Ele encontra um velho que seria seu avô e, sob a tempestade, é jogado ao mar. A cadela desaparece, e reaparece latindo páginas depois.

No romance de Galera, o protagonista é seguidamente oposto ao irmão, um ficcionista de não muito sucesso instalado em São Paulo. A mãe é quem contrapõe os dois filhos: um que foi para a grande cidade e o outro que foi para um lugar sem futuro. E apesar de todas essas pressões: a da mãe, a de praticamente todas as personagens de Garopaba que ele vai conhecendo, ele compreende que está no lugar certo. Tal um Édipo surfista, o protagonista de Barba ensopada de sangue sabe que está com razão em ir para onde está indo e em descobrir a verdade ao seu respeito, mesmo que todo mundo lhe diga para parar. Ele insiste em entrar na natureza sem ser chamado ou induzido e, além do seu controle, sem poder desvendar o mistério até onde quer, vai sendo pouco a pouco expulso, primeiro pela população nativa de Garopaba e então literalmente pelo mar, após o encontro com o velho misterioso. Quase inconsciente, em mar aberto, as ondas lhe impedem de continuar:

Uma gaivota aparece do nada e começa a voar em círculos sobre a sua cabeça. (...) Os círculos vão ficando mais fechados e sem mais nem menos o surfista tem certeza de que está recebendo um aviso para sair imediatamente da água. Vinha detectando uma série de variações muito mais sutis no mar, fenômenos invisíveis e difíceis de descrever. O fundo pedregoso começa a borbulhar. Rema com toda a força em direção à beira, eletrizado pelo medo, mirando um ponto fixo da areia. Quando já está no raso correndo com a água pelos joelhos finalmente olha para trás e vê ondas gigantes quebrando na laje, as ondas que dali em diante acreditará que o teriam afogado. (Galera, 2012: 369) 
Não é a primeira vez que Galera utiliza a imagem de uma natureza pouco convidativa. Cordilheira, seu romance anterior, conta a historia de uma jovem pessoa que decide passar uma temporada em Buenos Aires. A uma certa altura da história, após se envolver com um grupo de escritores, faz com seus novos amigos uma viagem para a Patagônia e, ao presenciar um ritual duvidoso que os amigos realizariam sob uma tempestade com resultados mortais, decide voltar para São Paulo. Não foi a experiência portenha, não foram exatamente os amigos: foi a visão terrível no topo de um abismo na Terra do Fogo que justificou o seu retorno à mesmice paulista.

O final de Barba ensopada de sangue vai num sentido semelhante. Depois de trezentas páginas passadas em busca de seu avô, o narrador sem nome agora somente com a cachorra e a barba crescida vai para os meios dos arbustos e breus nos arredores do vilarejo. Após a briga com o avô, no mar ("o mar que ele tanto adora ostentando sua faceta mais privada e destruidora") (id.: 369) que acaba por devolvê-lo à beira da praia, ele conclui que o melhor é permanecer na irresolução. A última manifestação da natureza no romance são os latidos da cachorra Beta e que culminarão numa cena assustadora para todo o povoado, como se o avô tivesse enfim se projetado (ou encarnado) sobre o neto, mas também como se todas as superstições de Garopaba tivessem se confirmado, e o rapaz ensanguentado fosse de fato uma força supernatural. $\mathrm{O}$ crescimento da barba nada mais é do que a "natureza fazendo seu curso" (id.:177) e a saga do protagonista nada mais é do que essa: como se tornar um perfeito homem do mato (id.:358). Não haveria sentido que o protagonista de Barba ensopada de sangue, como o irmão, seja um escritor ou que viva num circuito urbano. A paz para ele é pegar jacarés, o nado diário, e o repouso se não na natureza profunda que o rejeitará, ao menos no vilarejo praiano. Mas o "homem do mato" que ele vira não é como o vendedor de frutas de Tarsila do Amaral, vestido das cores da bandeira nacional e encarando o Atlântico à espera do saque; ao contrário, ele é um jovem calmo, sem pátria, latinha de 
cerveja na mão e o polegar rodando no controle do Playstation. O que ele guia são as pernas de um jogador de futebol.

\section{Finalmente}

Para explicar as deambulações de personagens no espaço dentro do tempo da intriga, através de uma espécie de quarta dimensão, Bakhtin inventou a noção de cronótopo. $O$ romance realista, no argumento de Bakhtin, iria muitas vezes no sentido de reforçar um cronótopo particular: o da passagem da personagem principal à grande capital, como numa metonímia da passagem à "modernidade" e da consciência do tempo histórico. Permanecer no ambiente rural seria sinal de isolação e autoctonismo; a grande cidade seria o cosmopolitismo, a promiscuidade cultural geral. Esse cronótopo, é o que os três romances comentados parecem mostrar, teria se tornado anacrônico; a metrópole não seria mais o único símbolo moderno - ao menos não nos mesmos termos -, a natureza não serviria mais à ficção de um país que tem a sua própria constituição e fronteiras como única motivação.

O subtexto ao longo desse artigo deve muito à imaginação de Edward Saïd. Esse é o argumento principal de Cultura e Imperialismo (e também no desdobramento no que conhecemos como estudos pós-coloniais): até que ponto ainda é válida a noção de essências nacionais? A partir de que ponto elas não representam mais uma figura eficaz de resistência, mas nativismos não raro sangrentos, irrefletidos, isolacionistas, etc. São ideias que de um modo ou outro têm percorrido múltiplos departamentos de Literatura Comparada nas últimas décadas: estão na noção de hibridez de Bhabha, de planetaridade de Spivak, nos questionamentos da pertinência dos departamentos de literatura nacional, nos estudos de tradução, nos métodos quantitativos de Franco Moretti, nas diversas tentativas de pensar epistemologicamente a noção de literatura 
mundial. O artigo de Luiz Costa Lima mencionado aponta para a mesma evidência: a dissolução progressiva e algo nostálgica entre a pátria e a literatura. O texto não é novo, data de 1996. Quase vinte anos depois, suas conclusões (Costa Lima, 2014) sobre a literatura nacional são mais ou menos as mesmas: de que a literatura não é mais tão nacional assim.

A escolha dos autores também não foi gratuita: Milton Hatoum, Bernardo Carvalho e Daniel Galera estão entre os poucos autores brasileiros contemporâneos traduzidos, o que quer simplesmente dizer que cruzaram as fronteiras e com sorte serão encontrados além das livrarias lusófonas especializadas. São escritores que pertencem a gerações diferentes, que vêm de pontos opostos do território nacional e que possuem motivações, estilo e público distintos. E as representações da natureza de cada um pertencem a paisagens específicas, embora possuam significados vinculados e exageradamente semelhantes apesar de tudo. Ainda que as experiências do Xingu, do litoral catarinense e dos arredores de Manaus sejam únicas - é certo que sucuris existem apenas na América do Sul -, não seria arriscado dizer também que um leitor estrangeiro poderia assimilar as imagens dos rios de Hatoum, dos arbustos de Carvalho e da praia de Galera, e os significados sombrios de cada uma dessas experiências, com o seu horizonte cultural. O mesmo não poderia ser dito de Macunaíma, ou o tal leitor poderia perder a intenção nacionalista sobre a qual repousa o projeto de Mário de Andrade. O mais importante no fim é compreender que a ambição de mundialização não significa atenuar ou diminuir as diferenças - certamente a intenção não é de "globalizar" (no sentido de homogeneizar ou norte-americanizar) a sucuri. Pelo contrário, a sucuri deve permanecer uma sucuri, um desafio que se por um lado é problemático para tradutores, por outro é o que possibilita a verdadeira nuance por trás da ideia de literatura mundial: a noção de que o planeta é ao mesmo tempo "um e desigual" (o termo é de Moretti: one and unequal), singular e assimétrico, esperando articulação. 
Uma observação final: este texto foi escrito nas semanas que precedem a Copa do Mundo no Brasil em 2014. Não seria necessário fazer uma nota de avacalhação contra o tipo de globalização que tem sido feita em torno do evento, à entrada violenta de capital estrangeiro em prol da exclusão de boa parte da população aos eventos (que sequer é gente aos olhos do governo brasileiro e da FIFA), à gentrificação massiva do Rio de Janeiro e aos crimes cometidos pela polícia para legitimar e agilizar o evento. Qualquer que tenha sido a minha argumentação em defesa da mundialização metafórica do território e da perda de sentido de nacionalismo, nada aqui defende ou serve para justificar essas sequências e o silêncio geral em torno delas. Fora do Maracanã, os que não estiverem apanhando durante os protestos vão ver os jogos em casa com a ronda circulando a esquina enquanto a Jennifer Lopez canta Forza! Forza! É de se imaginar que o olhar demente do Vendedor de Frutas talvez não tenha perdido em todo o seu significado.

\section{Bibliografia}

Anderson, Mark D.. "National Nature and Ecologies of Abjection in Brazilian Literature at the Turn of Twentieth Century". In Kane, Adrian Taylor (ed.). The Natural World in Latin American Literatures: Ecocritical Essays on Twentieth Century Writing, Jefferson, McFarland, 2010, p. 208-232.

Andrade, Mário de. Macunaíma, o herói sem nenhum caráter. edição crítica, São Paulo, ALLCA XX, 1996.

Andrade, Oswald de. Manifesto da Poesia Pau Brasil. disponível online em http://www.passeiweb.com/estudos/livros/manifesto_pau_brasil

Bakhtine, Mikhaïl. Esthétique et théorie du roman. Paris, Gallimard, 1987.

Brasiliana - Journal for Brazilian Studies. Vol. 3, n.1 (Jul. 2014). ISSN 2245-4373. 
Carvalho, Bernardo. Nove noites. São Paulo, Companhia das Letras, 2002.

Fisher, Luís Augusto. "Reféns da modernistrolatria". In: Revista Piauí, março de 2013, disponível em http://revistapiaui.estadao.com.br/edicao-80/questoes-de-literaturacultura/refens-da-modernistolatria

Galera, Daniel. Barba ensopada de sangue. São Paulo, Companhia das Letras, 2012.

Hatoum, Milton. Cinzas do Norte. São Paulo, Companhia das Letras, 2005.

. Órfãos do Eldorado. São Paulo, Companhia das Letras, 2008.

Lima, Luiz Costa. "Literatura e nação: esboço de uma releitura". In: Revista Brasileira de Literatura Comparada. Rio de Janeiro, ABRALIC, 1996, n. 3, pp. 33-39.

. "Respostas de Luiz Costa Lima". In: Folha de São Paulo, fevereiro de 2014, http://www1.folha.uol.com.br/ilustrissima/2014/02/1415832-respostas-de-luiz-costalima.shtml

Meltzer, Françoise. "What is Wrong with National Literature Departments?"in: D'haen, Theo (ed). Literature for Europe?. Amsterdam, Rodopi, 2009, pp. 43-60.

Moretti, Franco. Distant Reading. Londres, Verso, 2013.

Said, Edward. Culture and Imperialism. Londres, Vintage, 1994.

Schwarz, Roberto. Misplaced Places: Essays on Brazilian Culture. New York, Verso, 1992.

Spivak, G. C.. Death of a Discipline. New York, Columbia University Press, 2003.

Tosta, Antonio Luciano de A.. "Exchanging Glances: the streetcar, modernity, and the metropolis in Brazilian literature". In Chasqui, Volumen XXX, 2/noviembre 2001, Arizona State University, 2001, p.35-52. 